DOI: https://10.15407/kvt197.03.033

UDC 681.5

L.S. ZHITECKII ${ }^{1}, \mathrm{PhD}$ (Engineering),

Acting Head of the Intelligent Automatic Systems Department

e-mail: leonid zhiteckii@i.ua

V.N. AZARSKŌ ${ }^{2}$, DSc. (Engineering), Professor,

Chief of the Aerospace Control Systems Department,

e-mail: azarskov@nau.edu.ua

K.Yu. SOLOVCHUK ${ }^{3}$,

Assistant of the Department of Computer Information Technologies and Systems

e-mail: solovchuk_ok@ukr.net

${ }^{1}$ International Research and Training Center for Information Technologies

and Systems of the National Academy of Sciences of Ukraine

and Ministry of Education and Science of Ukraine,

40, Acad. Glushkov av., Kyiv, 03187, Ukraine

${ }^{2}$ National Aviation University, Kyiv, Ukraine.

1, Kosm. Komarova av., Kyiv, 03680, Ukraine

${ }^{3}$ Poltava National Technical Yuri Kondratyuk University, Poltava, Ukraine.

24, Pershotravneva av., Poltava, 36011, Ukraine

\title{
SOLVING A PROBLEM OF ADAPTIVE STABILIZATION FOR SOME STATIC MIMO SYSTEMS
}

Introduction. The adaptive stabilization of some classes of uncertain multivariable static plants with arbitrary unmeasurable bounded disturbances is addressed in this article. The cases where the number of the control inputs does not exceed the number of the outputs are studied. It is assumed that the plant parameters defining the elements of its gain matrix are unknown. Again, the rank of this matrix may be arbitrary. Meanwhile, bounds on external disturbances are supposed to be known. The problem stated and solved in this work is to design adaptive controllers to be able to ensure the boundedness of the all input and output system's signals in the presence of parameter uncertainties.

The purpose of the paper is to show that it is possible to stabilize any uncertain multivariable static plant which gain matrix may be either square or nonsquare and may have an arbitrary rank remaining unknown for the designer.

Methods. The methods based on recursive point estimation of unknown plant parameters are utilized to design the adaptive inverse model-based controller.

Results. The asymptotic properties of the adaptive controllers have been established. Simulation results have been presented to support the theoretic studies. 
Conclusion. The adaptive control laws proposed in the paper can guarantee the boundedness of all the signals generated by the feedback control systems. However, this important feature will achieve via an "overparameterization" of these systems. Nevertheless, the simulation experiments demonstrate their efficiency.

Keywords: adaptive control, boundedness, discrete time, estimation algorithm, feedback, multivariable system, uncertainty.

\section{INTRODUCTION}

The problem of efficient control of multivariable systems with arbitrary unmeasurable external disturbances stated several decades ago remains important both from theoretical and practical points of view until recently. Novel results in this scientific area have been reported in numerous papers and generalized in several books including [1-3]. This problem attracts an attention of many researchers dealing with the design of optimal controllers for controlling the so-called multi-inputs multi-outputs (MIMO) system by using different approaches.

Among other methods advanced in the modern control theory, the inverse model-based method that is an extension of the well-known internal model principle seems to be perspective in order to cope with arbitrary unmeasurable disturbances and to optimize some classes of multivariable control systems. It turned out that this method first intuitively advanced in [4] makes it possible to optimize the closed-loop control system containing the MIMO static (memoryless) plants whose gain matrices are square and nonsingular. Since the beginning of the $21^{\text {st }}$ century, a significant progress has been achieved utilizing the inverse model-based approach, e.g., [5] and other works. Nevertheless, it is quite unacceptable if the MIMO plants to be controlled have singular square or else any nonsquare gain matrices because they are noninvertible.

To optimize the closed-loop control system containing an arbitrary MIMO static plant, the pseudoinverse model-based approach has been proposed and substantiated in [6]. Naturally enough that its gain matrix must be known to implement this approach. In practice, however, the plant parameters defining the elements of gain matrices may not be known a priori. In this case, the problem of designing the so-called robust multivariable control system may be stated.

The monographs [7-9] give a fairly full picture concerning the results achieved in the robust control theory to the beginning of the 2000s. Within the framework of this theory, the pseudoinverse model-based method has been modified in [10-12] to stabilize some classes of uncertain interconnected linear and nonlinear systems whose gain matrices are arbitrary. (Note that the problem of robust control of some nonlinear one-dimensional static plant has before been solved in the work [13].). Unfortunately, the pseudoinverse model-based controller having fixed parameters may not be suitable if the parameter uncertainty is great enough.

An adaptation concept plays a role of some universal tool to deal with the control of uncertain systems [8, 14-20], et al. This concept has been employed in the papers [21-23] in which adaptive controllers for controlling fix linear and nonlinear multivariable static plants have been designed and studied, assuming that their gain matrices are nonsingular square matrices. The latest results with respect to robust adaptive control of the linear and some nonlinear static plants having one output and several control inputs can be found in [8, chap. 3]. 
In [24], the adaptive pseudoinverse model-based control has been proposed to stabilize a nonsquare MIMO plant having the gain matrix of full rank in the absence of disturbances. Recently, the problem of the stabilization of singleinput multi-outputs (SIMO) static systems with bounded disturbances has been solved in [25]. In [26, 27] the adaptive control systems containing the interconnected plants with both square and nonsquare matrices of the nonfull ranks in the presence of bounded disturbances have been designed and argued.

Difficulties that take place when adaptive control use the point estimation algorithms are how to guarantee the stability (the boundedness) of the closedloop system [28]. See also [14, 15]. To overcome these difficulties in the case of the singular square system, the so-called fictitious plant to be controlled adaptively has been introduced in the closed-loop circuit [26]. The idea of the simultaneous adaptive control of the true and of fictitious plants advanced in this work turned out fruitful to deal with adaptive stabilization of any MIMO static plants irrespective of the ranks of their gain matrices [27].

The purpose of the paper is to generalize results obtained in [26, 27] and to show that within the framework of the adaptive approach, it is possible to stabilize the arbitrary MIMO static uncertain plant without knowledge concerning both the elements and also rank of its gain matrix.

\section{STATEMENT OF THE PROBLEM}

Let

$$
y_{n}=B u_{n-1}+v_{n-1}
$$

be the equation describing a MIMO plant with measurable $m$-dimensional output vector, unmeasured $m$-dimensional disturbance vector and the $r$-dimensional control vectors related to the $n$th discrete time $(n=1,2, \ldots)$ are $y_{n}=\left[y_{n}^{(1)}, \ldots, y_{n}^{(m)}\right]^{T}, \quad v_{n}=\left[v_{n}^{(1)}, \ldots, v_{n}^{(m)}\right]^{T}$ and $u_{n}=\left[u_{n}^{(1)}, \ldots, u_{n}^{(r)}\right]^{T}$, respectively. $B$ represents some time-invariant $m \times r$ gain matrix given by

$$
B=\left(\begin{array}{ccc}
b^{(11)} & \ldots & b^{(1 r)} \\
\ldots & \ldots & \ldots \\
b^{(m 1)} & \ldots & b^{(m r)}
\end{array}\right) .
$$

Consider the class of MIMO plants, where the number $r$ of the control inputs is not less than two, but does not exceed the number $m$ of the outputs, i.e., $2 \leq r \leq m$.

The following assumptions with respect to the gain matrix $B$ and the sequences $\left\{v_{n}^{(i)}\right\}=v_{0}^{(i)}, v_{1}^{(i)}, \ldots$ are made.

A1. The elements of the matrix $B$ in (2) are all unknown. However, there are some interval estimates

$$
\underline{b}^{(i j)} \leq b^{(i j)} \leq \bar{b}^{(i j)}, \quad i=1, \ldots, m, \quad j=1, \ldots, r
$$

with the known upper and lower bounds $\underline{b}^{(i j)}$ and $\bar{b}^{(i j)}$, respectively. This implies that $B$ may be singular, in principle. 
A2. The rank of $B$ remaining unknown, in general, may be arbitrary number which satisfies

$$
1 \leq \operatorname{rank} B \leq r(=\min \{r, m\}) .
$$

A3. $\left\{v_{n}^{(i)}\right\} \quad(i=1, \ldots, m)$ are all the arbitrary scalar sequences bounded in modulus according to

$$
\left|v_{n}^{(i)}\right| \leq \varepsilon_{i}<\infty
$$

where $\varepsilon_{i} \mathrm{~s}$ are constant. For simplicity of exposition, it is assumed that they are known.

Denote by $y^{0}=\left[y^{0(1)}, \ldots, y^{0(m)}\right]^{T}$ the desired $m$-dimensional output vector. Without loss of generality, suppose $\left|y^{0(1)}\right|+\ldots+\left|y^{0(m)}\right| \neq 0$ implying that $0<\left\|y^{0}\right\|<\infty \quad\left(y^{0(i)} \equiv\right.$ const $\left.\forall i=1, \ldots, m\right)$.

Define the output error vector

$$
e_{n}=y^{0}-y_{n} .
$$

of the current errors $e_{n}^{(i)}=y^{0(i)}-y_{n}^{(i)}$ for each ith output $y_{n}^{(i)}$ giving $e_{n}=\left[e_{n}^{(1)}, \ldots, e_{n}^{(m)}\right]^{T}$. Then the control objective is to design an adaptive controller stabilizing the unknown plant (1). More exactly within the framework of assumptions A1) - A3), it is required to guarantee the ultimate boundedness of the sequences $\left\{e_{n}\right\}$ and $\left\{u_{n}\right\}$ in the form

$$
\begin{aligned}
& \limsup _{n \rightarrow \infty}\left\|e_{n}\right\|<\infty, \\
& \limsup _{n \rightarrow \infty}\left\|u_{n}\right\|<\infty .
\end{aligned}
$$

\section{THE CASE OF SQUARE NONSINGULAR GAIN MATRICES}

Suppose that $B$ is a square nonsingular $r \times r$ matrix meaning $r=m$ and

$$
\operatorname{det} B \neq 0 \text {. }
$$

In this case, the control law may be chosen as in [17, sect. 4.2] setting

$$
u_{n}=u_{n-1}+B_{n}^{-1} e_{n},
$$

where $e_{n}$ is given by (6), and $B_{n}^{-1}$ denotes the matrix obtained via the inversion of the current estimate matrix $B_{n}$ for unknown $B$.

According to $\left[17\right.$, sect. 4.2], the rows of $B_{n}$ defining the vectors $b_{n}^{(i)}=\left[b_{n}^{(i 1)}, \ldots, b_{n}^{(i r)}\right]^{\mathrm{T}} \quad(i=1, \ldots, r)$ are updated by exploiting the recursive adaptation algorithm 


$$
b_{n}^{(i)}= \begin{cases}b_{n-1}^{(i)} & \text { if }\left|e_{n}^{(i)}\right| \leq \varepsilon_{i}^{0}, \\ b_{n-1}^{(i)}-\gamma_{n}^{(i)} \frac{e_{n}^{(i)}-\bar{\varepsilon}_{i} \text { signe } e_{n}^{(i)}}{\left\|\nabla u_{n-1}\right\|_{2}^{2}} \nabla u_{n-1} & \text { otherwise. }\end{cases}
$$

In this expression, $e_{n}^{(i)}$ represents the $i$ th component of $e_{n}$ given by (6). $\|x\|_{2}$ denotes the Euclidean norm of some $s$-dimensional vector $x=\left[x^{(1)}, \ldots, x^{(s)}\right]^{\mathrm{T}}$ determined as $\|x\|_{2}=\sqrt{\left[x^{(1)}\right]^{2}+\ldots+\left[x^{(s)}\right]^{2}}$. The variable $\nabla u_{n}:=u_{n}-u_{n-1}$ is the increment of $u_{n} . \varepsilon_{i}^{0} \mathrm{~s}$ are arbitrary fixed numbers satisfying

$$
\varepsilon_{i}^{0}>\bar{\varepsilon}_{i}=2 \varepsilon_{i}, \quad i=1, \ldots, r .
$$

The coefficients $\gamma_{n}^{(i)}$ s are chosen as

$$
0<\underline{\gamma}^{(i)} \leq \gamma_{n}^{(i)} \leq \bar{\gamma}^{(i)}<2
$$

to ensure

$$
\operatorname{det} B_{n} \neq 0 .
$$

The asymptotical behavior of the adaptive control algorithm (10), (11) together with (12) to (14) is given in the theorem below.

Theorem 1. Consider the closed-loop stabilization system containing the plant (1) and the feedback adaptive controller described in the expressions (10)-(14). If the conditions (5) and (9) are satisfied then the control objectives (7) and (8) are achieved.

Proof. Follows from the results presented in [14, subsect. 4.2.3].

\section{THE CASE OF SQUARE SINGULAR GAIN MATRICES}

Let $B$ be a square singular $r \times r$ matrix, i.e.,

$$
\operatorname{det} B=0 \text {. }
$$

Basic idea to deal with a matrix $B$ satisfying (15) is the transition from the adaptive identification of the true plant having the singular gain matrix $B$ to the adaptive identification of a fictitious plant with the nonsingular gain matrix $\widetilde{B}$ of the form

$$
\widetilde{B}=B+\delta_{0} I_{r},
$$

where $I_{r}$ denotes the identity $r \times r$ matrix and $\delta_{0}$ is a fixed quantity [26].

Although $\widetilde{B}$ as well as $B$ remain unknown, the requirement

$$
\operatorname{det} \widetilde{B} \neq 0
$$

can always be satisfied by the suitable choice of.$\delta_{0}$ in (16). In fact, each $i$ th eigenvalue $\lambda_{i}(B)$ of $B$ lies in one of the $r$ closed regions of the complex $z$ plane consisting of all the Gerŝgorin discs [29, p. 146]: 


$$
\left|z-b^{(i i)}\right| \leq \sum_{\substack{j=1 \\ j \neq i}}^{r}\left|b^{(i j)}\right|, \quad i=1, \ldots, r
$$

Since, at least, one of the eigenvalues $\lambda_{i}(B)$ is equal to zero (due to the singularity of $B$ ), by virtue of (17) there are the numbers

$$
\underline{\beta}^{(i)}:=b^{(i i)}-\sum_{\substack{j=1 \\ j \neq i}}^{r}\left|b^{(i j)}\right|, \quad \bar{\beta}^{(i)}:=b^{(i i)}+\sum_{\substack{j=1 \\ j \neq i}}^{r}\left|b^{(i j)}\right|
$$

such that if

$$
\left|b^{(i 1)}\right|+\ldots+\left|b^{(i r)}\right| \neq 0
$$

then either $\underline{\beta}^{(i)} \leq 0$ but $\bar{\beta}^{(i)}>0$ or $\underline{\beta}^{(i)}<0$ but $\bar{\beta}^{(i)} \geq 0$. These numbers are defined as the intersection of the $i$ th Gerŝgorin disc with the real axis of the complex $z$-plane as show in Figs 1 and 2, respectively, left. In both cases, $\underline{\beta}^{(i)} \bar{\beta}^{(i)} \leq 0$ if (20) is satisfied because $\underline{\beta}^{(i)}$ and $\bar{\beta}^{(i)}$ cannot have the same sign.
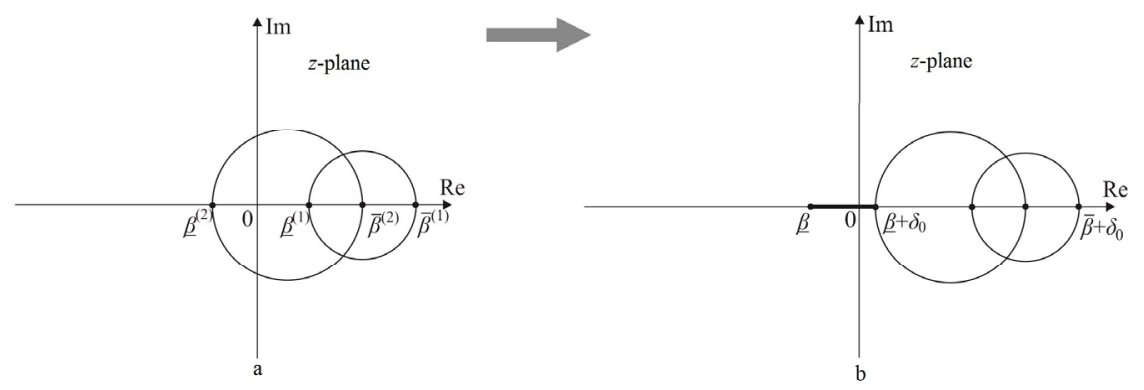

Fig. 1. The Gerŝgorin discs for $r=2$ in the case $\left|\underline{\beta}^{(2)}\right|<\left|\bar{\beta}^{(1)}\right|$
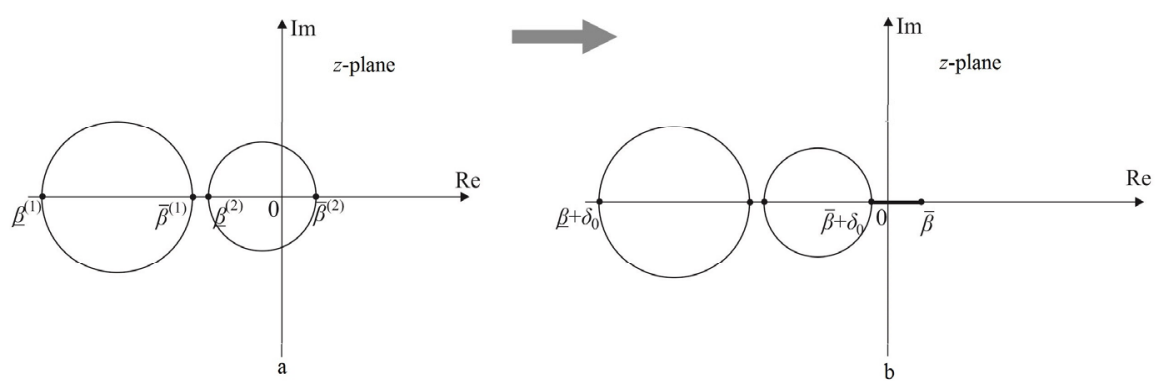

Fig. 2. The Gerŝgorin discs for $r=2$ in the case $\left|\bar{\beta}^{(2)}\right|<\left|\underline{\beta}^{(1)}\right|$ 
Denoting

$$
\underline{\beta}:=\min \left\{\underline{\beta}^{(1)}, \ldots, \underline{\beta}^{(r)}\right\}, \quad \bar{\beta}:=\max \left\{\bar{\beta}^{(1)}, \ldots, \bar{\beta}^{(r)}\right\},
$$

consider the following two cases: a) $|\underline{\beta}|<|\bar{\beta}|$; b) $|\underline{\beta}|>|\bar{\beta}|$ (The case when $|\underline{\beta}|=|\bar{\beta}|$ can be combined with any two cases.) In order to go to the gain matrix $\widetilde{B}$ of the fictitious plant having the form (16) in the case a), it is sufficient to shift the Gerŝgorin disc (18) right taking

$$
\delta_{0}>|\underline{\beta}|
$$

as shown in Fig. 1, right. In the case b), the discs (9) need to be shifted left according to

$$
\delta_{0}<-|\bar{\beta}|
$$

See Fig. 2, right. In both cases, the nonsingularity of $\widetilde{B}$ is guaranteed. Nevertheless, the conditions (22) and (23) cannot be satisfied, as yet. In fact, the numbers $\underline{\beta}$ and $\bar{\beta}$ given by the expressions (21) depend of $\underline{\beta}^{(i)}$ and $\bar{\beta}^{(i)} \mathrm{s}$ defined by (19). But they are unknown because $b^{(i j)} \mathrm{s}$ are all unknown.

The following actions are proposed to choose a number $\delta_{0}$ satisfying (17). Introduce

$$
\begin{aligned}
& \underline{\beta}_{\min }^{(i)}:=\underline{b}^{(i i)}-\sum_{\substack{j=1 \\
j \neq i}}^{r} \max \left\{\left|\underline{b}^{(i j)}\right|,\left|\bar{b}^{(i j)}\right|\right\}, \\
& \bar{\beta}_{\max }^{(i)}:=\bar{b}^{(i i)}+\sum_{\substack{j=1 \\
j \neq i}}^{r} \max \left\{\left|\underline{b}^{(i j)}\right|,\left|\bar{b}^{(i j)}\right|\right\},
\end{aligned}
$$

minimizing and maximizing in $b^{(i j)} \in\left[\underline{b}^{(i j)}, \bar{b}^{(i j)}\right]$ the right sides of (19) for $\underline{\beta}^{(i)}$ and $\bar{\beta}^{(i)}$, respectively.

Further, the number $\delta_{0}$ is found to satisfy the conditions

$$
\begin{array}{ll}
\delta_{0}>-\underline{\beta}_{\min } \text { if } & \left|\underline{\beta}_{\text {min }}\right|<\left|\bar{\beta}_{\max }\right|, \\
\delta_{0}<-\bar{\beta}_{\max } \text { if } & \left|\underline{\beta}_{\text {min }}\right|>\left|\bar{\beta}_{\max }\right|,
\end{array}
$$

where $\underline{\beta}_{\min }, \bar{\beta}_{\max }$ represent some quantities defined as follows:

$$
\begin{aligned}
& \underline{\beta}_{\min }:=\min \left\{\underline{\beta}_{\min }^{(1)}, \ldots, \underline{\beta}_{\min }^{(r)}\right\}, \\
& \bar{\beta}_{\max }:=\max \left\{\bar{\beta}_{\max }^{(1)}, \ldots, \bar{\beta}_{\max }^{(r)}\right\} .
\end{aligned}
$$


It can be clarified that if (25) together with (24) and (26) will be satisfied then the condition (17) will without fail be ensured.

After determining the quantity $\delta_{0}$ we can proceed to the consideration of the fictitious plant. Since the input variables $u_{n}^{(1)}, \ldots, u_{n}^{(r)}$ and the disturbances $v_{n}^{(1)}, \ldots, v_{n}^{(N)}$ of both true plant and fictitious plant are the same, this feature makes it possible to describe our fictitious plant by the equation

$$
\widetilde{y}_{n}=\widetilde{B} u_{n-1}+v_{n-1},
$$

similar to (1). In this equation, $\widetilde{y}_{n}=\left[\tilde{y}_{n}^{(1)}, \ldots, \tilde{y}_{n}^{(r)}\right]^{\mathrm{T}}$ denotes the output vector of the fictitious plant.

It is interesting that the components of $\tilde{y}_{n}$ can be measured while the components of $v_{n}$ in (28) remain unmeasurable. In fact, substituting (16) into (27) due to (1) we produce

$$
\tilde{y}_{n}=y_{n}+\delta_{0} u_{n-1} .
$$

It is seen from (28) that $\tilde{y}_{n}$ can always be found indirectly having $u_{n}$ and $y_{n}$ to be measured.

Now, our problem reduces to the known problem of adaptive control applicable to the fictitious plant (27) with the unknown gain matrix $\widetilde{B}$ in the presence of arbitrary bounded disturbances $v_{n}^{(1)}, \ldots, v_{n}^{(r)}$. Its solving follows the steps of the section above. Namely, the adaptive control law is designed in the form

$$
u_{n}=u_{n-1}+\widetilde{B}_{n}^{-1} \widetilde{e}_{n},
$$

in which, instead of the current estimate $B_{n}$ of $B$, another $\widetilde{B}_{n}$ is exploited, and the error vector $e_{n}$ defined in (6) is replaced by

$$
\widetilde{e}_{n}=y^{0}-\widetilde{y}_{n}
$$

with $\tilde{y}_{n}$ given by the expression (28).

The adaptive identification algorithm used to determine the estimates $\widetilde{B}_{n}$ may be taken as

$$
\widetilde{b}_{n}^{(i)}= \begin{cases}\widetilde{b}_{n-1}^{(i)} & \text { if }\left|\widetilde{e}_{n}^{*(i)}\right| \leq \varepsilon_{i}^{0}, \\ \widetilde{b}_{n-1}^{(i)}+\gamma_{n}^{(i)} \frac{\widetilde{e}_{n}^{*(i)}-\bar{\varepsilon}_{i} \operatorname{sign} \widetilde{e}_{n}^{*(i)}}{\left\|\nabla u_{n-1}\right\|_{2}^{2}} \nabla u_{n-1} & \text { otherwise, } i=1, \ldots, r,\end{cases}
$$

which is similar to (11). In this algorithm, $\varepsilon_{i}^{0}$ and $\bar{\varepsilon}_{i}$ are given by (12).

$$
\widetilde{e}_{n}^{*(i)}=\nabla \widetilde{y}_{n}^{(i)}-\widetilde{b}_{n-1}^{(i) \mathrm{T}} \nabla u_{n-1}
$$

represent the $i$ th component of the identification error $\tilde{e}_{n}^{*}$ given as 


$$
\widetilde{e}_{n}^{*}=\nabla \widetilde{y}_{n}-\widetilde{B}_{n-1} \nabla u_{n-1}
$$

where $\nabla \widetilde{y}_{n}^{(i)}:=\widetilde{y}_{n}^{(i)}-\widetilde{y}_{n-1}^{(i)}$, and the notation $\widetilde{b}_{n}^{(i) \mathrm{T}}:=\left[\widetilde{b}_{n}^{(i)}, \ldots, \widetilde{b}_{n}^{(i r)}\right]$ of the $i$ th row of $\widetilde{B}_{n}$ is introduced. The coefficients $\gamma_{n}^{(i)}$ s are chosen as in (13) to

$$
\operatorname{det} \widetilde{B}_{n} \neq 0 \text {. }
$$

The feedback adaptive robust control system described in the equations (1), (29), (31) is designed as depicted in Fig. 3. In this figure, the notation $\nabla \widetilde{y}_{n}^{*}:=\widetilde{B}_{n-1} \nabla u_{n-1}$ is introduced.

The asymptotic properties of the adaptive control system are established in the following theorem.

Theorem 2. Determine $\delta_{0}$ using the formula (25) together with (24) and (26), and choose an arbitrary initial $\widetilde{B}_{0}=B_{0}+\delta_{0} I$ with $B_{0}=\left\{b_{0}^{(i j)}\right\}$ whose elements satisfy the conditions $\underline{b}^{(i j)} \leq b_{0}^{(i j)} \leq \bar{b}^{(i j)}$. Subject to assumptions A1 - A3, the adaptive controller described in the equations (29), (31) together with (28), (30) when applied to the plant (1) yields (7), (8).

Proof. See [26].

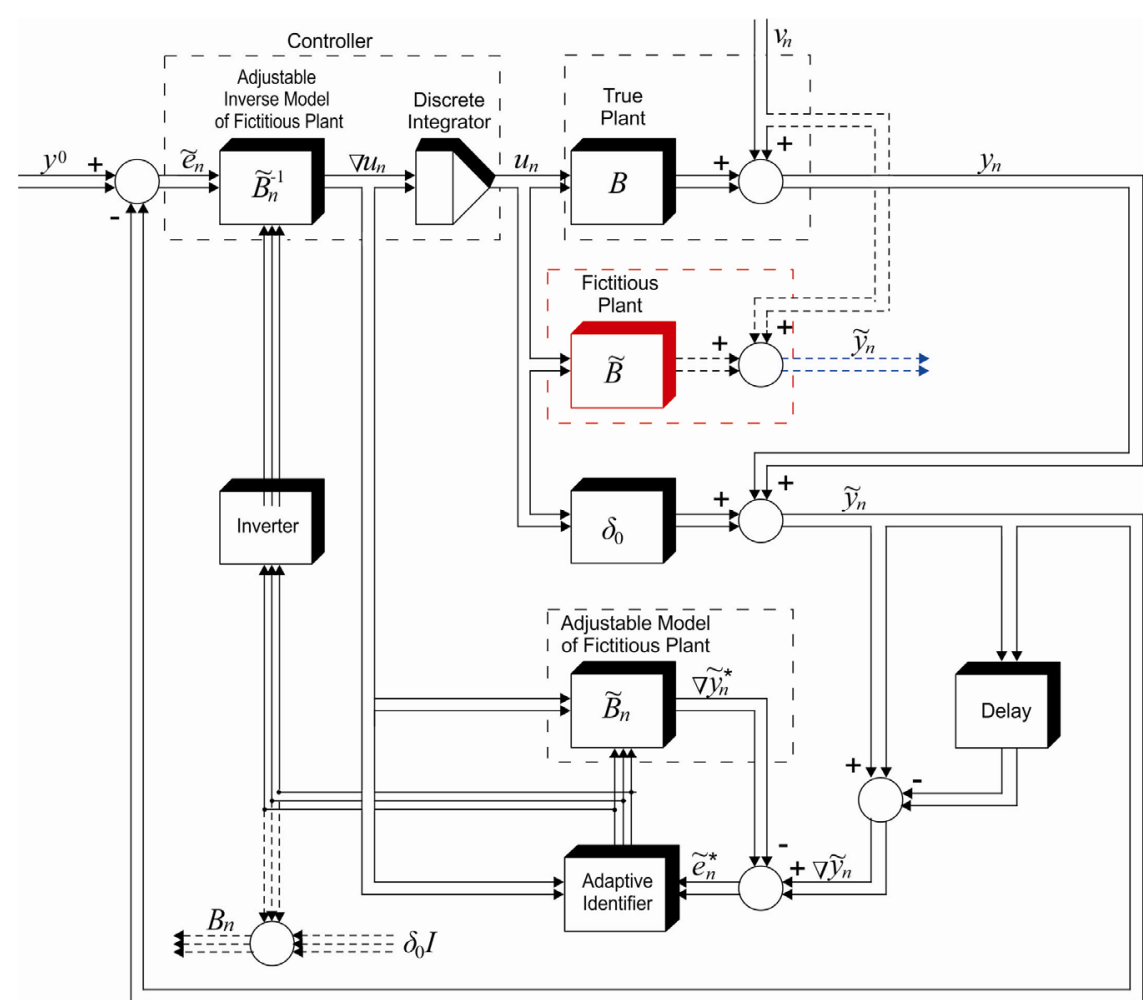

Fig. 3. Configuration of adaptive stabilization system 


\section{THE CASE OF NONSQUARE GAIN MATRICES WITH ARBITRARY RANKS}

Let $B$ be a nonsquare $m \times r$ matrix of the form (2) with unknown rank satisfying (4). Define the so-called submatrices $B\left[i_{1}[k], \ldots, i_{r}[k] \mid 1, \ldots, r\right] \in \mathbf{R}^{r \times r}[29$, part I, subsect. 2.2] whose rows represent the rows of $B$ with the numbers $i_{1}[k], \ldots, i_{r}[k]\left(1 \leq i_{1}[k]<\ldots<i_{r}[k] \leq m\right)$. The quantity of these matrices is equal to $N=\left(\begin{array}{c}m \\ r\end{array}\right)$. Denoting by $B[k]$ the submatrix which corresponds to a $k$ th subset $\left\{i_{1}[k], \ldots, i_{r}[k]\right\}$, write the equations of some $k$ plants as:

$$
y_{n}[k]=B[k] u_{n-1}+v_{n-1}[k], \quad k=1, \ldots, N,
$$

where $y_{n}[k]=\left[y_{n}^{\left(i_{1}[k]\right)}, \ldots, y_{n}^{\left(i_{r}[k]\right)}\right]^{\mathrm{T}} \in \mathbf{R}^{r}$, and $v_{n}[k]=\left[v_{n}^{\left(i_{i}[k]\right)}, \ldots, v_{n}^{\left(i_{r}[k]\right)}\right]^{\mathrm{T}} \in \mathbf{R}^{r}$.

In accordance with the approach proposed in the previous section, pass from (35) to the equations of the fictitious plants described by

$$
\widetilde{y}_{n}[k]=\widetilde{B}[k] u_{n-1}+v_{n-1}[k], \quad k=1, \ldots, N
$$

with the same $u_{n-1}$ and $v_{n-1}[k]$. In these equations, $\tilde{y}_{n}[k]$ denotes the $r$ dimensional output vector related to the $k$ th fictitious plant whose gain matrix $\widetilde{B}[k]$ is defined as follows:

$$
\widetilde{B}[k]=B[k]+\delta_{0}[k] I_{r},
$$

where $\delta_{0}[k]$ is a fixed quantity depending on $k$. This quantity is calculated for each $k=1, \ldots, N$ using the technique described in the previous section. Namely, taking into account the constraints (3), $\delta_{0}[k]$ can always be found to ensure

$$
\operatorname{det} \widetilde{B}[k] \neq 0 \quad \forall k=1, \ldots, N .
$$

It follows from (35) to (37) that

$$
\tilde{y}_{n}[k]=y_{n}[k]+\delta_{0}[k] u_{n-1} .
$$

This expression shows that although as $\widetilde{B}[k]$ as $B[k]$ remain unknown, however, the components of all $N$ the vectors $\widetilde{y}_{n}[k]$ can indirectly be "measured" after measuring the components of $y_{n}$ and $u_{n-1}$, and it is essential.

If the conditions (38) are satisfied, then the problem of the adaptive stabilization of the true plant (1) can be reduced to the problem of simultaneous adaptive stabilization of all $N$ fictitious plants (36) with unknown but nonsingular $r \times r$ gain matrices $\widetilde{B}[k] \quad(k=1, \ldots, N)$ via forming at each $n$th time instant a set of $N$ different "potentially" possible controls $u_{n}[1], \ldots, u_{n}[N]$ and selecting one of them in accordance with certain choice rule [27] given below. 
Following to [27], the adaptive control law to be applicable to any fictitious plant is designed in the form

$$
u_{n}[k]=u_{n-1}+\widetilde{B}_{n}^{-1}[k] \widetilde{e}_{n}[k], \quad k=1, \ldots, N,
$$

where $\widetilde{e}_{n}[k]=y^{0}[k]-\widetilde{y}_{n}[k]$ with $y^{0}[k]=\left[y^{0\left(i_{1}[k]\right)}, \ldots, y^{0\left(i_{r}[k]\right)}\right]^{\mathrm{T}}$ defines the output error vector related to the $k$ th fictitious plant at the $n$th time instant, and $\widetilde{B}_{n}[k] \in \mathbf{R}^{r \times r}$ is the current estimate of unknown $r \times r$ matrix $\widetilde{B}[k]$ at the same time instant satisfying

$$
\operatorname{det} \widetilde{B}_{n}[k] \neq 0 \quad \forall k=1, \ldots, N .
$$

As the adaptation algorithms, the standard recursive procedures for the adaptive identification of each $k$ th fictitious plant (35) described by

$$
\widetilde{b}_{n}^{(i)}[k]= \begin{cases}\widetilde{b}_{n-1}^{(i)}[k] & \text { if }\left|\widetilde{e}_{n}^{*(i)}[k]\right| \leq \varepsilon_{i}^{0}, \\ \widetilde{b}_{n-1}^{(i)}[k]+\gamma_{n}^{(i)} \frac{\widetilde{e}_{n}^{*(i)}[k]-\bar{\varepsilon}_{i} \operatorname{sign} \widetilde{e}_{n}^{*(i)}[k]}{\left\|\nabla u_{n-1}\right\|_{2}^{2}} \nabla u_{n-1} & \text { otherwise, } \\ i=1, \ldots, r, \quad k=1, \ldots, N & \end{cases}
$$

are proposed. In these algorithms, $\widetilde{b}_{n}^{(i)}[k]$ denotes the $r$-dimensional estimate vector obtained by transposing the $i$ th row of $\widetilde{B}_{n}[k]$, and

$$
\widetilde{e}_{n}^{*(i)}[k]=\widetilde{y}_{n}^{(i)}[k]-\widetilde{y}_{n-1}^{(i)}[k]-\widetilde{b}_{n-1}^{(i) \mathrm{T}}[k] \nabla u_{n-1}
$$

represents the scalar variable making sense of the $i$ th component of $\widetilde{e}_{n}^{*}[k] \in \mathbf{R}^{r}$ that is the identification error vector related to the $k$ th fictitious plant. The coefficients $\gamma_{n}^{(i)}$ s are chosen from the ranges $\left[\underline{\gamma}^{(i)}, \bar{\gamma}^{(i)}\right]$ (similarly to that in (13)) to ensure the requirement (41).

Next, add the adaptation algorithms described in the formulas (42) together with (43) by an algorithm for estimating unknown $B$ defined as follows:

$$
b_{n}^{(i)}= \begin{cases}b_{n-1}^{(i)} & \text { if }\left|e_{n}^{*(i)}\right| \leq \varepsilon_{i}^{0}, \\ b_{n-1}^{(i)}+\gamma_{n}^{(i)} \frac{e_{n}^{*(i)}-\bar{\varepsilon}_{i} \operatorname{sign} e_{n}^{*(i)}}{\left\|\nabla u_{n-1}\right\|_{2}^{2}} \nabla u_{n-1} & \text { otherwise, } i=1, \ldots, m,\end{cases}
$$

where $b_{n}^{(i) \mathrm{T}}$ represents the $i$ th row of the estimate matrix $B_{n}$, and

$$
e_{n}^{*(i)}=y_{n}^{(i)}-y_{n-1}^{(i)}-b_{n-1}^{(i) \mathrm{T}} \nabla u_{n-1}
$$


is the $i$ th component of the identification error vector $e_{n}^{*}=y_{n}-y_{n-1}-B_{n-1} \nabla u_{n-1}$ ( $\bar{\varepsilon}_{i}$ and $\varepsilon_{i}^{0}$ are given by (12)) .

The estimation procedure defined in (44) together with (45) makes it possible to estimate the $m$ predicted output errors $\vec{e}_{n+1}^{(i)}[k](i=1, \ldots, m)$ for the each $i$ th output of true plant (1) at any $n$ using the formula

$$
\left|\vec{e}_{n+1}^{(i)}[k]\right|=\left|y^{0(i)}-b_{n}^{(i) \mathrm{T}} u_{n}[k]\right|+\varepsilon^{(i)}, \quad i=1, \ldots, m .
$$

The synthesis of the adaptive controller is finished by the choice of the control $u_{n}$ from the set $\left\{u_{n}[1], \ldots, u_{n}[N]\right\}$ with $u_{n}[k]$ given by (40). This choice is implemented by the rule giving the minimum of the 1 -norm of $\vec{e}_{n+1}[k]=\left[\vec{e}_{n+1}^{(1)}[k], \ldots, \vec{e}_{n+1}^{(m)}[k]\right]^{\mathrm{T}}$ as

$$
u_{n}=\arg \min _{u_{n}[k]} \sum_{i=1}^{m}\left|\vec{e}_{n+1}^{(i)}[k]\right|,
$$

where $\vec{e}_{n+1}^{(i)}[k] \mathrm{s}$ are specified by (46).

Remark. The definition of the 1-norm $\|\cdot\|_{1}$ can be found in [7, p. 260].

The asymptotic properties of the adaptive controller described in this section are given in theorem below (the main result).

Theorem 3. Consider the feedback control system containing the plant (1) in which $r<m$, and the adaptive controller defined in (42), (47) together with (39), (46) and (41). Using the constants (3), determine $\delta_{0}[1], \ldots, \delta_{0}[N]$ to satisfy (38). Let assumption A1-A3 be valid. Then, this controller applied to plant (1) guarantees that the control objectives (7) and (8) will be achieved.

Proof. Follows the lines of [14, chap. 4]. (Due to space limitation, details are omitted.)

Note that Theorem 3 does not guarantee that the ultimate error $\lim _{n \rightarrow \infty} \sup \left\|e_{n}\right\|$ will become as in the nonadaptive case when there is no parameter uncertainty and the pseudoinverse model-based controller proposed in [6] can by applied.

\section{SIMULATION}

A simulation experiment was conducted to illustrate the performance of the proposed adaptive control in the case when $r=2, m=3$. As the gain matrix,

$$
B=\left(\begin{array}{cc}
4 & 2 \\
2 & 1 \\
3 & 1.5
\end{array}\right)
$$


with nonfull rank (rank $B=1$ ) was taken. Since $N=3$, it produces the following three submatrices:

$$
B[1]=\left(\begin{array}{ll}
4 & 2 \\
2 & 1
\end{array}\right), \quad B[2]=\left(\begin{array}{cc}
4 & 2 \\
3 & 1.5
\end{array}\right) \text { and } B[3]=\left(\begin{array}{cc}
2 & 1 \\
3 & 1.5
\end{array}\right) .
$$

Further, the three vectors $y_{n}[1]=\left[y_{n}^{(1)}, y_{n}^{(2)}\right]^{\mathrm{T}}, \quad y_{n}[2]=\left[y_{n}^{(1)}, y_{n}^{(3)}\right]^{\mathrm{T}}$ and $y_{n}[3]=\left[y_{n}^{(2)}, y_{n}^{(3)}\right]^{\mathrm{T}}$ was introduced to describe the plants (35) having the gain matrices $B[1], B[2]$ and $B[3]$, respectively.

The quantities $\delta_{0}[1]=1.1, \delta_{0}[2]=1.2$ and $\delta_{0}[3]=1.3$ guaranteeing $\widetilde{B}[k]$ to be nonsingular were derived from (3). The initial $\widetilde{B}_{0}[1], \widetilde{B}_{0}[2]$ and $\widetilde{B}_{0}[3]$ were chosen as $\widetilde{B}_{0}[k]=B_{0}[k]+\delta_{0}[k] I_{r}$ with the initial elements of $B_{0}[k]$ which were selected from $B$ inside the corresponding ranges $\left[\underline{b}^{(i j)}, \bar{b}^{(i j)}\right]$ specified as follows: $\quad b^{(11)} \in[1,5], b^{(12)} \in[0,2], \quad b^{(21)} \in[0,2], \quad b^{(22)} \in[1,2], \quad b^{(31)} \in[1,4]$, $b^{(32)} \in[0,5]$. Namely, we set $b_{0}^{(11)}=1, \quad b_{0}^{(12)}=1 \quad b_{0}^{(21)}=0, \quad b_{0}^{(22)}=1.9, \quad b_{0}^{(31)}=2$, $b_{0}^{(32)}=2.1$. The desired output vector was given as $y^{0}=[1,3,7]^{\mathrm{T}}$.

The performance of the simulated adaptive control system with the disturbance sequences $\left\{v_{n}^{(i)}\right\}=v_{0}^{(i)}, v_{1}^{(i)}, \ldots$ generated as some pseudorandom i.i.d. variables taken from $-0.1 \leq v_{n}^{(1)} \leq 0.1,-0.2 \leq v_{n}^{(2)} \leq 0.2,-0.08 \leq v_{n}^{(3)} \leq 0.08$ is presented in Figs. 4 and 5.

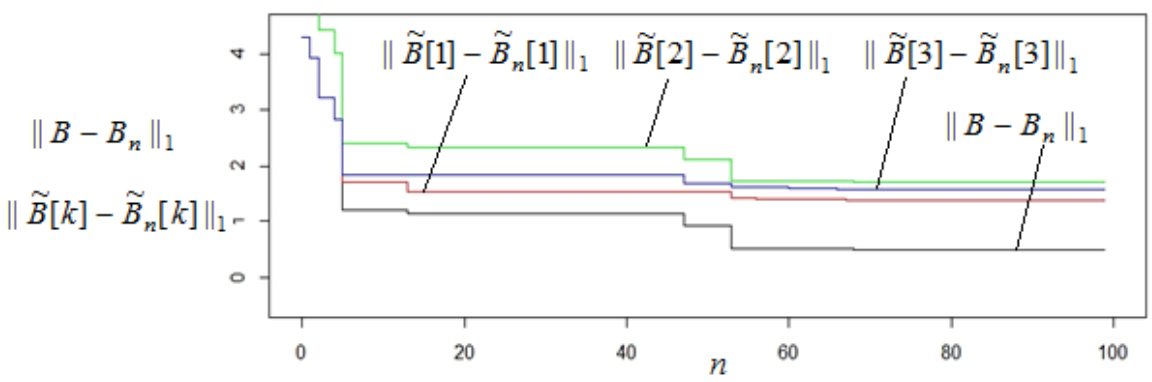

Fig. 4. Variables describing the adaptive estimation processes 

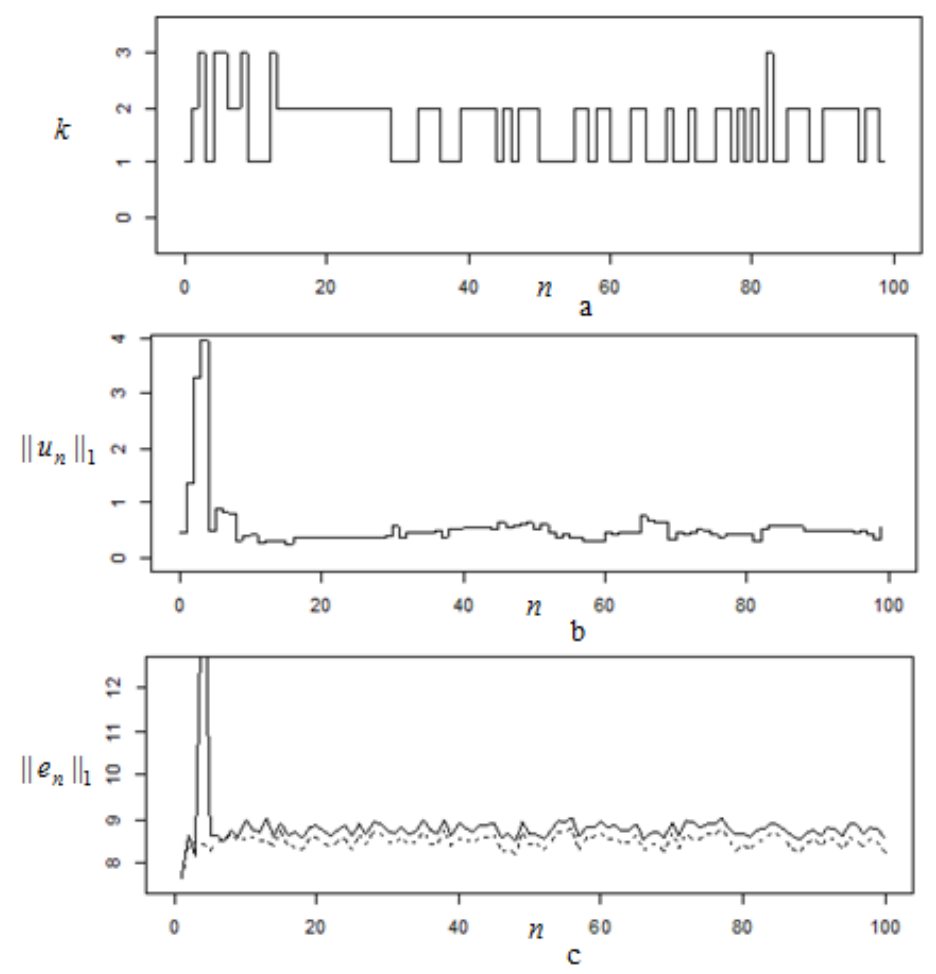

Fig. 5. The behavior of the control system: a) the current number $k$ of control $u_{n}[k]$ chosen from $\left\{u_{n}[1], u_{n}[2], u_{n}[3]\right\}$ at given $n ; \mathrm{b}$ ) the 1-norm of control vector; $c$ ) the 1-norm of output vector in adaptive case (solid line) and in nonadaptive optimal case (dashed line)

Figs. 5, a - c demonstrate that the performance of the proposed adaptive controller applied to the static MIMO plant having some nonsquare gain matrix with nonfull rank is successful enough.

\section{CONCLUSION}

It has been established that the adaptive control laws can guarantee the boundedness of all the signals generated by the feedback control systems. However, this important feature will achieve via an "overparameterization" of these systems. Nevertheless, the simulation experiments demonstrate their efficiency.

\section{REFERENCES}

1. Maciejowski J. M. Multivariable Feedback Design. Wokinghan: Addison-Wesley, 1989. 490 p.

2. Skogestad S., Postlethwaite I. Multivariable Feedback Control. UK, Chichester: Wiley, 1996. $592 \mathrm{p}$.

3. Albertos P., Sala A. Multivariable Control Systems: An Engineering Approach. London: Springer, 2006. $340 \mathrm{p}$.

4. Pukhov G. E., Zhuk K. D. Synthesis of Interconnected Control Systems via Inverse Operator Method. Kiev: Nauk. dumka, 1966. 218 p. (in Russian).

5. Lyubchyk L. M. Disturbance rejection in linear discrete multivariable systems: inverse model approach. Proc. 18th IFAC World Congress (28 Aug-2 Sep, 2011, Milano, Italy). Milano, 2011. P. 7921-7926. 
6. Skurikhin V. I., Gritsenko V. I., Zhiteckii L. S., Solovchuk K. Yu. Generalized inverse operator method in the problem of optimal controlling linear interconnected static plants. Dopovidi NAN Ukrainy 2014. no. 8. P. 57-66. (in Russian).

7. Polyak, B.T., Shcherbakov, P. S. Robust Stability and Control. Moscow: Nauka, 2002. 303 p. (in Russian).

8. Kuntsevich V. M. Control under Uncertainty: Guaranteed Results in Control and Identification Problems. Kyiv: Nauk. dumka, 2006. 264 p. (in Russian).

9. Sokolov V.F. Robust Control with Bounded Disturbances. Syktyvkar: Komi Scientific Center, Ural Branch of the RAS, 2011. 218 p. (in Russian).

10. Zhiteckii L. S., Solovchuk K. Yu. Pseudoinversion in the problems of robust stabilizing multivariable discrete-time control systems of linear and nonlinear static objects under bounded disturbances. Journal of Automation and Information Sciences. 2017. vol. 49. no. 5, P. 35-48.

11. Zhitetskii L. S., Skurikhin V. I., Solovchuk K. Yu. Stabilization of a nonlinear multivariable discrete-time time-invariant plant with uncertainty on a linear pseudoinverse model. Journal of Computer and Systems Sciences International. 2017. vol. 56. no. 5. P. 759-773.

12. Zhiteckii L. S., Azarskov V. N., Solovchuk K. Yu., Sushchenko O. A. Discrete-time robust steady-state control of nonlinear multivariable systems: a unified approach. Proc. 19th IFAC World Congress $\left(24^{\text {th }}-29^{\text {th }}\right.$ of Aug, 2014, Cape Town, South Africa). Cape Town, 2014 P. 8140-8145.

13. Bunich A.L. On some nonstandard problems of the synthesis of discrete systems. Autom. Remote Control. 2000. no. 6. P. 994-1002.

14. Fomin V. N., Fradkov A. L., Yakubovich V. A. Adaptive Control of Dynamic Plants. Moscow: Nauka, 1981. (in Russian).

15. Goodwin G.C., Sin K.S. Adaptive Filtering, Prediction and Control. Engewood Cliffs, NJ.: Prentice-Hall, 1984. 540 p.

16. Landau I. D., Lozano R., M'Saad M. Adaptive Control. London: Springer, 1997. 590 p.

17. Zhiteckii L. S., Skurikhin V. I. Adaptive Control Systems with Parametric and Nonparametric Uncertainties. Kyiv: Nauk. dumka, 2010. 301 p. (in Russian).

18. Narendra K. S., Annaswamy A. M. Stable Adaptive Systems. NY: Dover Publications, 2012. $895 \mathrm{p}$.

19. Ioannou P., Sun J. Robust Adaptive Control. NY: Dover Publications, 2013. 852 p.

20. Aström K. J., Wittenmark B. Adaptive Control: 2nd Edition. NY: Dover Publications, 2014. $577 \mathrm{p}$.

21. Bakan G.M., Volosov V.V., Salnikov N.N. Adaptive control of a linear static plant by a model with unknown parameters. Kibernetika. 1984. no. 2. P. 63-68.

22. Lublinskii B.S., Fradkov A.L. Adaptive control of nonlinear statistical processes with an implicit characteristic. Autom. Remote Control. 1983. no. 4. P. 510-518.

23. Bakan G.M. Adaptive control of a multi-dimensional static process under nonstatistical uncertainty. Autom. Remote Control. 1987. no. 1. P. 76-88.

24. Zhiteckii L. S., Solovchuk K. Yu. Adaptive stabilization of some multivariable systems with nonsquare gain matrices of full rank. Cybernetics and Computer Engineering. 2018. no. 2. P. 44-61.

25. Zhiteckii L. S., Solovchuk K. Yu. Robust adaptive pseudoinverse model-based control of an uncertain SIMO memoryless system with bounded disturbances. Proc. IEEE 2nd Ukraine Conference on Electrical and Computer Engineering $\left(2^{\text {nd }}-6^{\text {th }}\right.$ of Jul, 2019, UKRCON-2019, Lviv). Lviv, 2019. P. 628-633.

26. Azarskov V.N., Zhiteckii L.S., Solovchuk K.Yu. Parametric identification of the interconnected static closed-loop system: a special case. Proc. 12th All-Russian Control Problems Council (16 - 19 Jun, VSPU-2014), Moscow, 2014 P. 2764-2776.

27. Zhiteckii L.S., Azarskov V.N., Solovchuk K.Yu. Adaptive robust control of interconnected static plants with nonsquare gain matrixes. Proc. 13th All-Russian Control Problems Council (17 - 20 Jun, VSPU-2019), Moscow, 2019. 6 p.

28. Anderson B.D.O., Bitmead R.R., Johnson C.R., Kokotovic P.V., Kosut R.L., Mareels I.M.Y., Praly L., and Riedle B.D. Stability of Adaptive Systems: Passivity and Averaging Analysis. USA, Mas.: MIT Press. 1986. 340 p. 
29. Marcus M., Minc H. A Survey of Matrix Theory and Matrix Inequalities. Boston: Aliyn and Bacon, 1964. 208p.

Received 30.05.2019

\section{ЛІТЕРАТУРА}

1. Maciejowski J. M. Multivariable Feedback Design. Wokinghan: Addison-Wesley, 1989. 409 p.

2. Skogestad S., Postlethwaite I. Multivariable Feedback Control. UK, Chichester: Wiley, 1996. $592 \mathrm{p}$.

3. Albertos P., Sala A. Multivariable Control Systems: an Engineering Approach. London: Springer, 2006. 340p.

4. Пухов Г.Е., Жук К.Д. Синтез многосвязных систем управления по методу обратных операторов. Киев: Наук. думка, 1966. 218 с.

5. Lyubchyk L. M. Disturbance rejection in linear discrete multivariable systems: inverse model approach. Prep. 18th IFAC World Congress, Milano, 2011. P. 7921-7926.

6. Скурихин В.И., Гриценко В.И., Житецкий Л.С., Соловчук К.Ю. Метод обобщенного обратного оператора в задаче оптимального управления линейными многосвязными статическими объектами. Доклады НАН Украины. 2014. №8. С. 57-66.

7. Поляк Б.Т., Щербаков П.С. Робастная устойчивость и управление. М.: Наука, 2002. 303 с.

8. Кунцевич В. М. Управление в условиях неопределенности: гарантированные результаты в задачах управления и идентификации. Киев: Наук. думка, 2006. 264c.

9. Соколов В.Ф. Робастное управление при ограниченных возмущениях. Сыктывкар: Коми научный центр УрО РАН, 2011. 218 с.

10. Zhitetskii L. S., Skurikhin V. I., Solovchuk K. Yu. Stabilization of a nonlinear multivariable discrete-time time-invariant plant with uncertainty on a linear pseudoinverse model. Journal of Computer and Systems Sciences International. 2017. vol. 56. no. 5. P. 759-773.

11. Zhiteckii L. S., Solovchuk K. Yu. Pseudoinversion in the problems of robust stabilizing multivariable discrete-time control systems of linear and nonlinear static objects under bounded disturbances. Journal of Automation and Information Sciences. 2017. vol. 49. no. 5. P. 35-48.

12. Zhiteckii L. S., Azarskov V. N., Solovchuk K. Yu., Sushchenko O. A. Discrete-time robust steady-state control of nonlinear multivariable systems: a unified approach. Proc. 19th IFAC World Congress $\left(24^{\text {th }}-29^{\text {th }}\right.$ of Aug, 2014, Cape Town, South Africa). Cape Town, 2014 P. 8140-8145.

13. Bunich A.L. On some nonstandard problems of the synthesis of discrete systems. Autom. Remote Control. 2000. no. 6. P. 994-1002.

14. Фомин В.Н., Фрадков А. Л., Якубович В. А. Адаптивное управление динамическими объектами. М.: Наука, 1981. 448 с.

15. Goodwin G.C., Sin K.S. Adaptive Filtering, Prediction and Control. Engewood Cliffs, NJ.: Prentice-Hall, 1984. 540 p.

16. Landau I. D., Lozano R., M'Saad M. Adaptive Control. London: Springer, 1997. 590 p.

17. Житецкий Л.С., Скурихин В.И. Адаптивные системы управления с параметрическими и непараметрическими неопределенностями. Киев: Наук. думка, 2010. 301 с.

18. Narendra K. S., Annaswamy A. M. Stable Adaptive Systems. NY: Dover Publications, 2012.895 p.

19. Ioannou P., Sun J. Robust Adaptive Control. NY: Dover Publications, 2013. 852 p.

20. Aström K. J., Wittenmark B. Adaptive Control: 2nd Edition. NY: Dover Publications, 2014. $577 \mathrm{p}$.

21. Бакан Г.М., Волосов В.В., Сальников Н.Н. Адаптивное управление линейным статическим объектом по модели с неизвестными параметрами. Кибернетика. 1984. № 2. C. 63-68.

22. Lublinskii B.S., Fradkov A.L. Adaptive control of nonlinear statistical processes with an implicit characteristic. Autom. Remote Control. 1983. no. 4. P. 510-518.

23. Bakan G.M. Adaptive control of a multi-dimensional static process under nonstatistical uncertainty. Autom. Remote Control. 1987. no. 1. P. 76-88.

24. Zhiteckii L. S., Solovchuk K. Yu. Adaptive stabilization of some multivariable systems with nonsquare gain matrices of full rank. Кибернетика и вычислительная техника, 2018. № 2. P. 44-61. 
25. Zhiteckii L. S., Solovchuk K. Yu. Robust adaptive pseudoinverse model-based control of an uncertain SIMO memoryless system with bounded disturbances. Proc. IEEE 2nd Ukraine Conference on Electrical and Computer Engineering $\left(2^{\text {nd }}-6^{\text {th }}\right.$ of Jul, 2019UKRCON-2019, Lviv). Lviv, Ukraine, 2019, P. 628-633.

26. Азарсков В.Н., Житецкий Л.С., Соловчук К.Ю. Параметрическая идентификация многосвязного статического объекта в замкнутом контуре управления: специальный случай. Труды 12-го Всероссийского совещания по проблемам управления (ВСПУ-2014), Москва: ИПУ, 2014. С. 2764-2776.

27. Житецкий Л.С., Азарсков В.Н., Соловчук К.Ю. Адаптивное робастное управление многосвязными статическими объектами с прямоугольными матрицами коэффициентов усиления. Труды 13-го Всероссийского совещания по проблемам управления (ВСПУ-2019), Москва: ИПУ, 2019. 6 с.

28. S Stability of Adaptive Systems: Passivity and Averaging Analysis / Anderson B.D.O., Bitmead R.R., Johnson C.R et. al. USA, Mas.: MIT Press. 1986. 340 p.

29. Marcus M., Minc H. A Survey of Matrix Theory and Matrix Inequalities. Boston: Aliyn and Bacon, 1964. 208 p.

Отримано 30.05.2019

Л.С. Житеиькийำ, канд. техн. наук,

в.о. зав. відд. інтелектуальних автоматичних систем

e-mail: leonid_zhiteckii@i.ua

B.M. Азарсков ${ }^{2}$, д-р техн. наук, професор,

зав. каф. аерокосмічних систем керування

e-mail: azarskov@nau.edu.ua

К.Ю. Соловчук $\kappa^{3}$, аспірантка,

асистентка каф. комп'ютерних інформаційних

технологій та систем

e-mail: solovchuk_ok@ukr.net

${ }^{1}$ Міжнародний науково-навчальний центр інформаційних

технологій та систем НАН України і МОН України, пр. Акад. Глушкова, 40, м. Київ, 03187, Україна

${ }^{2}$ Національний авіаційний університет,

пр. Космонавта Комарова, 1, м. Київ, 03680, Україна

${ }^{3}$ Полтавський національний технічний університет імені Юрія Кондратюка, пр. Першотравневий, 24, м. Полтава, 36011, Україна

\section{РОЗВ'ЯЗУВАННЯ ОДНІСЇ ЗАДАЧІ АДАПТИВНОЇ СТАБІЛІЗАЦІЇ ДЕЯКИХ СТАТИЧНИХ МІМО СИСТЕМ}

Вступ. У статті розглянуто задачу адаптивної стабілізації деяких класів невизначених багатовимірних статичних об'єктів з довільними невимірними обмеженими збуреннями. Досліджено випадки, коли кількість входів керування не перевищує кількість виходів. Припущено, що параметри об'єкта, що визначають елементи матриці коефіцієнтів підсилення, невідомі. Окрім того, ранг цієї матриці може бути довільним. Водночас, межі зовнішніх збурень повинні бути відомі. Поставлена та вирішена у роботі задача полягає в тому, щоб побудувати адаптивний регулятор, здатний забезпечити обмеженість всіх вхідних і вихідних сигналів системи за наявності параметричних невизначеностей.

Мета статті - показати, що можна стабілізувати довільний невизначений багатовимірний статичний об'єкт, матриця коефіцієнтів підсилення якого може бути квадратною або прямокутною і мати довільний ранг, залишаючись невідомою конструктору системи.

Методи. Методи, що базуються на рекурентному точковому оцінюванні невідомих параметрів об'єкта, використовуються для побудови адаптивного регулятора на основі оберненої моделі. 
Результати. Встановлено асимптотичні властивості адаптивних регуляторів. Щоб підкріпити теоретичні дослідження, надано результати моделювання.

Висновки. Адаптивні закони керування, що пропонуються в статті, можуть гарантувати обмеженість всіх сигналів, що генеруються системами керування зі зворотним зв'язком. Однак це важлива властивість буде досягатися за рахунок «зверхпараметризації» цих систем, і модельні експерименти показують їхню ефективність.

Ключові слова: адаптивне керування, обмеженість, дискретний час, алгоритм оиінювання, зворотний зв'язок, багатовимірна система, невизначеністью.

Л.С. Житеикий ${ }^{1}$ канд. техн. наук,

и.о. зав. отд. интеллектуальных автоматических систем

e-mail: leonid_zhiteckii@i.ua

B.Н. Азарсков $\overline{2}$, д-р. техн. наук, профессор,

зав. кафедрой аэрокосмических систем управления

e-mail: azarskov@nau.edu.ua

К.Ю. Соловчук, аспирантка

ассистентка каф. компьютерных информационных технологий и систем

e-mail: solovchuk_ok@ukr.net

${ }^{1}$ Международный научно-учебный центр информационных технологий

и систем НАН Украины и МОН Украины,

пр. Аккад. Глушкова, 40, г. Киев, 03187, Украина

${ }^{2}$ Национальный авиационный университет,

пр. Космонавта Комарова, 1, г. Киев, 03680, Украина

${ }^{3}$ Полтавский национальный технический университет имени Юрия Кондратюка, пр. Первомайский, 24, г. Полтава, 36011, Украина

\section{РЕШЕНИЕ ОДНОЙ ЗАДАЧИ АДАПТИВНОЙ СТАБИЛИЗАЦИЯ НЕКОТОРЫХ СТАТИЧЕСКИХ МИМО СИСТЕМ}

Введение. В статье рассмотрена задача адаптивной стабилизации некоторых классов неопределенных многомерных статических объектов с произвольными неизмеряемыми ограниченными возмущениями. Исследованы случаи, когда количество входов управления не превышает количество выходов. Предположено, что параметры объекта, определяющие элементы ее матрицы коэффициентов усиления, неизвестны. Кроме того ранг этой матрицы может быть произвольным. Между тем, границы внешних возмущений должны быть известны. Задача, которая была поставлена и решена в работе, состоит в том, чтобы построить адаптивный регулятор, способный обеспечить ограниченность всех входных и выходных сигналов системы при наличии параметрических неопределенностей.

Цель статьи - показать, что можно стабилизировать любой неопределенный многомерный статический объект, матрица коэффициентов усиления которого может быть квадратной или прямоугольной и иметь произвольный ранг, оставаясь неизвестной конструктору системы.

Методы. Методы, основанные на рекуррентном точечном оценивании неизвестных параметров объекта, используются для построения адаптивного регулятора на основе обратной модели.

Результаты. Установлены асимптотические свойства адаптивных регуляторов. Чтобы подкрепить теоретические исследования, представлены результаты моделирования.

Выводы. Адаптивные законы управления, предложенные в статье, могут гарантировать ограниченность всех сигналов, генерируемых системами управления с обратной связью. Однако это важное свойство будет достигаться за счет «сверхпараметризации» этих систем. В тоже время, модельные эксперименты показывают их эффективность.

Ключевые слова: адаптивное управление, ограниченность, дискретное время, алгоритм оченивания, обратная связь, многомерная система, неопределенность. 